\title{
Refractory Hormone Receptor Positive Breast Carcinoma
}

National Cancer Institute

\section{Source}

National Cancer Institute. Refractory Hormone Receptor Positive Breast Carcinoma. NCI Thesaurus. Code C157057.

Hormone receptor positive breast carcinoma that does not respond to treatment. 